\title{
La ciencia y el comportamiento
}

En más de treinta años de epidemia de VIH ha habido mayor avance en los abordajes biomédicos que en aquellos abocados al comportamiento o a superar las barreras estructurales. Hoy, de acuerdo con las directrices establecidas, se trata a todas las personas con VIH luego de ser diagnosticadas. Pero el concepto "tratar a todos" se encuentra, por ahora, más en la letra que en la práctica. Según el contexto, algunas personas con $\mathrm{VIH}$ esperan semanas o meses para iniciar su tratamiento antirretroviral y muchas de ellas se pierden en los meandros burocráticos y nunca acceden.

Hace dos años tomó mucha fuerza algo que ya sabíamos diecinueve años atrás y que hoy es un hecho científico ampliamente probado: una persona $\mathrm{VIH}+$ con carga viral indetectable no puede transmitir el virus. "Indetectable es igual a Intransmisible (I=I)" es epidemiológica y clínicamente muy significativo, mucho más si se considera el estigma, el auto-estigma y la discriminación. Alivia a las personas con VIH que están en tratamiento de sentirse "sujetos infecciosos". Y seguramente tendrá un correlato en incentivar el acceso a las pruebas diagnósticas bajo la lógica me trato, no me enfermo ni contagio (con el perdón del término).

No debemos menospreciar el desafío que nuestro país enfrenta con el diagnóstico tardío, donde se estima que tres de cada diez personas con VIH conocen su serología cuando sus CD4 son menores a 200. La incapacidad de aumentar el número de individuos que reciben en forma oportuna su diagnóstico es una de las principales causas de no poder controlar el número de nuevas infecciones.

Muchos dirán que estamos en una meseta, como si esto fuera en sí mismo una buena noticia. No lo es. Alrededor de 5800 personas resultan VIH positivas al año. Para dimensionarlos, los números necesitan una representación más gráfica. Por ejemplo, esta cifra equivale a los pasajeros que caben en veintiún vuelos de Aerolíneas, en el avión más grande de la flota. Por otro lado, en 2016 se han notificado 1494 muertes por complicaciones relacionadas con el sida, aunque seguramente cuando se sistematicen los datos de 2019 este número habrá bajado. Volviendo a la metáfora aeronáutica, en este caso hablamos de cinco aviones, pero fatalmente accidentados. Si este fuera el caso sería noticia y un tema relevante en la gestión de gobierno. Pero aún con estos números escalofriantes el $\mathrm{VIH} /$ sida se viene cayendo de la agenda de muchos actores.

Hace unos años la ciencia nos puso a disposición otra herramienta clave para prevenir la transmisión del VIH, la profilaxis pre-exposición (PrEP), reduciendo a nulas las posibilidades de resultar infectadas para las personas con comportamientos que los exponen al virus y a las infecciones de transmisión sexual (ITS). Sin embargo, la PrEP genera diversos sentimientos encontrados. Por mencionar uno, parece que su oferta minaría el uso de los preservativos. Se estima que en la mayoría de los países de nuestra región, cuatro de cada diez personas usan preservativos. Esto lo sabíamos 
mucho antes de que se descubriera el uso de los antiretrovirales (ARV) para blindar a las personas $\sin \mathrm{VIH}$ de un posible contagio. No se ha probado una compensación del riesgo: las personas que usan la PrEP no tienen más relaciones sexuales, como tampoco abandonan el uso del preservativo. Los modelos de implementación del suministro de PrEP incluyen la promoción y entrega de los preservativos.

En esta línea podríamos poner en duda la eficacia de muchas de las intervenciones comportamentales para la prevención del $\mathrm{VIH}$, pues solo en salud modificar los hábitos de riesgo es una de las cosas más difíciles, en general, y en particular si incluimos el comportamiento sexual ( $98 \%$ de las personas adquieren el VIH en relaciones sexuales no protegidas).

Durante décadas hemos intentado inútilmente modificar y gestionar las prácticas sexuales de las personas, y hemos sido lentos en reconocer nuestro fracaso. Pero más lentos aún hemos sido en introducir alguna innovación, por ejemplo, a la luz de la aparición de nuevos medios, redes sociales y aplicaciones que ayudan a conocer parejas sexuales.

Entre los recursos para la prevención, sin lugar a dudas el condón es la herramienta más económica y accesible. Sin embargo, es muy poco usado. Y esta afirmación la sustenta la tasa de embarazos no deseados y la transmisión de ITS. Un preservativo que se queda en el bolsillo, envuelto, que no se usa, transforma a esta en una intervención más costosa económica y sanitariamente.

Necesitamos incrementar el número de personas diagnosticadas, en particular de las poblaciones clave. Debemos tratar de inmediato a aquellas que resultan positivas, ofrecer la PrEP junto con los preservativos y la debida consejería informativa para la adherencia a este abordaje y cumplir con el derecho a la información promoviendo la noción de I=I. Hipotéticamente, si hacemos todo esto, podremos por fin reducir el número de nuevas infecciones y la morbi-mortalidad del VIH.

\section{Javier Hourcade Bellocq}

Red Global de Personas con VIH

Editor de Corresponsales Clave 